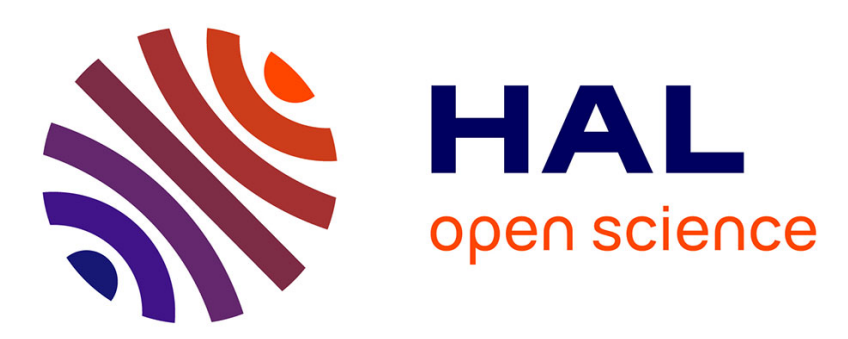

\title{
Variability in energy cost of running at the end of a triathlon and a marathon
}

Christophe Hausswirth, A. Xavier Bigard, M. Berthelot, M. Thomaïdis, C. Y. Guezennec

\section{- To cite this version:}

Christophe Hausswirth, A. Xavier Bigard, M. Berthelot, M. Thomaïdis, C. Y. Guezennec. Variability in energy cost of running at the end of a triathlon and a marathon. International Journal of Sports Medicine, 1996, 17 (8), pp.572 - 579. hal-01781727

\section{HAL Id: hal-01781727 https://hal-insep.archives-ouvertes.fr/hal-01781727}

Submitted on 30 Apr 2018

HAL is a multi-disciplinary open access archive for the deposit and dissemination of scientific research documents, whether they are published or not. The documents may come from teaching and research institutions in France or abroad, or from public or private research centers.
L'archive ouverte pluridisciplinaire HAL, est destinée au dépôt et à la diffusion de documents scientifiques de niveau recherche, publiés ou non, émanant des établissements d'enseignement et de recherche français ou étrangers, des laboratoires publics ou privés. 


\title{
Variability in energy cost of running at the end of a triathlon and a marathon
}

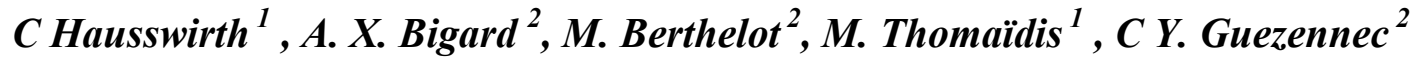 \\ ${ }^{1}$ Laboratoire de Biomécanique et de Physiologie, Institut National du Sport et de l'Education Physique, Paris, France \\ ${ }^{2}$ Département de Physiologie Systémique, Centre d'Études et de Recherches de Médecine Aérospatiale, Brétigny sur Orge, \\ France
}

Corresponding Author: C. Hausswirth, Institut National du Sport et de l'Education Physique Laboratoire de Biomécanique et de Physiologie, 11, avenue du Tremblay F-75012 Paris (France)

\begin{abstract}
The aim of this study was to investigate the increase in energy cost of running occurring at the end of a triathlon and a marathon event and to link them to the metabolic and hormonal changes, as well as to variations in stride length. Seven subjects took part in 3 experimental situations: a 2 h 15 min triathlon (30 min swimming, 60 min cycling and 45 min running), a 2 h 15 min marathon (MR) were the fast 45 min were run at the same speed as the triathlon run (TR), and a 45 min isolated run (IR) done at triathlon speed. The results show that energy cost during MR was higher than during TR $(\mathrm{p}<0.01)(+8.9 \%)$. Similar observations were made for pulmonary ventilation $(+7.9 \%)$ and heart rate $(+6.3 \%)$. Moreover, the values were significantly greater than the values obtained during the IR. TR and MR lead to greater weight loss $(\mathrm{p}<0.01)(2.4 \pm 0.3 \mathrm{~kg})$ than IR $(1 \pm 0.2 \mathrm{~kg})$. The triathlon and the marathon produced a large decrease in plasma volume (respectively $19.6 \pm 1.4 \%$ and $12.9 \pm 1.1 \%$ ) compared to IR $(2 \pm 0.4 \%)$. Plasma renin activity was higher for the triathlon and the marathon than for the IR $(\mathrm{p}<0.01)$. MR produces a significantly greater increase in plasma free fatty acids (F.F.A.) than TR $(p<0.05)$ and IR $(p<0.01)$. In addition, the F.F.A. at the end of TR were significantly higher than IR $(\mathrm{p}<0.05)$. At the end of the trial the mean stride lengths for TR and IR were greater $(+15 \%)(\mathrm{p}<0.01)$ than for MR. This study, carried out with subjects running overground, confirms the decrease in running efficiency previously shown at the end of a laboratory triathlon, and demonstrates that this decrease is lower than that occurring during a marathon. Key words: Triathlon, marathon, dehydration, running efficiency, energy cost of running, stride length
\end{abstract}

\section{Introduction}

With the emergence of relatively recent endurance sports like the triathlon, involving consecutive trials in swimming, cycling and running, the athlete is faced with a new challenge. As for other endurance sports, the main determinating factor of performance appears to be the ability to produce a large amount of energy at high speed for a long time (29). The triathlon is an example of a continuous event comprising of three different activities. These three events have evolved due to the probable efficacy of cross-training which has been suggested to promote physiologic adaptations not necessarily obtained when training for a single endurance event (34).

For exercices lasting more than two hours (e.g. marathon), it has been shown that the running economy decreased at the end of a long distance run (20,37). Whether an impairment of running economy occurs at the end of triathlon races after the athletes have performed swimming and cycling remains to be determined. Boone and Kreider (1986) have studied the effect of a three minutes pedalling exercise done on an ergocycle at $80 \%$ of the maximum 


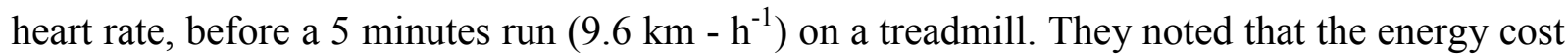
of running was higher when it was carried out after a warm-up on the ergocycle than when it was performed after a warm-up on the treadmill. Kreider et al. (1988) demonstrated that at the end of a simulated triathlon done in the laboratory $(800 \mathrm{~m}$ swim, $40 \mathrm{~km}$ cycling and $10 \mathrm{~km}$ run), oxygen uptake $\left(\mathrm{VO}_{2}\right)$, pulmonary ventilation $(\mathrm{VE})$, heart rate and the arteriovenous oxygen difference were greater during a $10 \mathrm{~km}$ triathlon run than during a single event $10 \mathrm{~km}$ run. They concluded that the cardiovascular modifications were the result of the need for greater thermoregulation during a $10 \mathrm{~km}$ triathlon run than during a control run. Although no direct measures have been performed during overground triathlon races, these results suggest that the running economy is altered by previous events (i.e. swimming and cycling).

Running economy, defined as the steady-state aerobic demand $\left(\mathrm{VO}_{2}\right)$ for a given running speed, has been identified as an important contributor to distance running success (28). A number of factors are known to affect running economy (28). Both physiological (e.g. core temperature) and biomechanical factors account for the variations in running economy. Earlier studies clearly showed that stride length is one of the biomechanical variables that affect running economy $(6,36)$. Some evidence exists that $\mathrm{VO}_{2}$ was lowest at stride lengths close to the self-selected values. Elliot and Roberts (1980) showed that during a 3000m race, a decrease in stride length and an increase in stride rate were associated with the appearance of fatigue. It may thus be hypothesized that a relation exists between fatigue, biomechanical factors such as stride length and stride rate, and running economy.

On the other hand, the effect of air and wind resistance on running economy has been questioned. McMiken and Daniels (1976) have not found any difference in $\mathrm{VO}_{2}$ for an exercise carried out on a treadmill and on the track where the running speeds are between 180 and $260 \mathrm{~m} \cdot \mathrm{min}^{-1}$. Similar data were provided by Bassett et al. (1985) when comparing the energy cost of level treadmill running versus overground running. When speed exceeded $280 \mathrm{~m}$ - min $^{-1}$ the energy cost of track running was greater than treadmill running (31). These results were supported by further experiments (11). Thus, the comparison between treadmill and overground data must be made with caution.

The aims of this study were

1) to verify that the decrease in running efficiency observed during a simulated triathlon in the laboratory was similarly recorded during an overground triathlon race,

2) to compare any decrease in running economy during a triathlon to any changes in energy cost found during a prolonged exercise bout of running $(5,37)$,

3) to compare any changes in hydration and metabolic parameters that occur during a triathlon and a marathon,

4) to determine any variations in stride length and study their relation with alterations in running economy.

\section{Materials and Methods}

\section{Subjects}

Four triathletes who currently take part in competitions and are trained for the triathlon and three duathlon specialists (running - cycling - running) who had never competed in a triathlon took part in this study. They volunteered to take part in the different tests and were informed in detail about the nature of the experiment and about possible risks. Written consent was given by all the subjects and a local Ethics Committee for the protection of individuals gave their approval of the project before its initiation. 
The average age of the subjects was $30 \pm 3$ years (range of $22-42$ ). Their body weight was $71.5 \pm 2.2 \mathrm{~kg}$ and the average height was $175.1 \pm 3.1 \mathrm{~cm}$. All subjects underwent a test to determine their maximum oxygen uptake $\left(\mathrm{VO}_{2} \max \right)$ on a treadmill with a $2 \%$ slope. The $\mathrm{VO}_{2} \mathrm{max}$, measured by a Sensormedic $2900 \mathrm{C}$ open circuit automatic gas analysis system (Sensormedic Horizon, U.S.A.) was on average $65.3 \pm 6 \mathrm{ml} \cdot \mathrm{min}^{-1}-\mathrm{kg}^{-1}$. The average experience of competing in the triathlon or duathlon was 4.52 .5 years. The best performance achieved in an Olympic triathlon (1.5 km swimming, $40 \mathrm{~km}$ cycling, $10 \mathrm{~km}$ running) ranged from $1 \mathrm{~h} 58 \mathrm{~min}$ to $2 \mathrm{~h} 35 \mathrm{~min}$. The data gathered indicate that the subjects are representative of triathletes (22).

\section{Experiment}

The subjects underwent 1 pre-test and 3 tests with at least 10 days between each test. All of the tests were carried out at the Institut National du Sport et de l'Education Physique. In the pretest the subjects swam for 30 minutes (free style) in an Olympic-size swimming pool. After 30 minutes passive recuperation, they cycled for one hour on a covered cycle track. This pre-test was done in order to familiarize the subjects with the material and facilities used. The first part of the experiment was an indoor simulated triathlon which consisted of 30 min swimming in a $50 \mathrm{~m}$ swimming pool, 60 min cycling on a $166 \mathrm{~m}$ track and 45 min running on a $340 \mathrm{~m}$ tartan paved circular track. The total time for the triathlon, not including changeover time was $2 \mathrm{~h} 15$ $\min$.

The instructions given to the triathletes for the swimming trial were to try to cover the same distances in the first and the second quarter of an hour. The subjects were given their times every $250 \mathrm{~m}$. Average water temperature was $23^{\circ} \mathrm{C}$. On the bicycle the subjects pedalled between 80 and $95 \mathrm{rev} \cdot \min ^{-1}(\mathrm{rpm})$. The athletes had to maintain the rate obtained after 10 min of cycling $( \pm 2 \mathrm{rpm})$ and could change the force requirement per pedal stroke when they liked, the experiment bicycles did not have a fixed gable. The freely chosen frequency often corresponded to that recorded during the pre-test. During the running, the athletes had to run as steadily as possible for $45 \mathrm{~min}$. The speed of each lap was calculated on the spot and given to the runner.

Each triathlete carried out the trial as if it was a real competition, in spite of the absence of a direct competitor. However, the 2 changeover times between the 3 trials were different from those in competition. The blood sampling done between swimming and cycling required a 3 min stop, followed by a 2 min run to reach the cycle track. Before the final 10 min of cycling, the blood sampling and the installation of the telemetric system required about $8 \mathrm{~min}$. Then the subject pedalled at the same speed as before with the telemetric system for $10 \mathrm{~min}$. The cycling-running changeover time was therefore reduced by 20 seconds for all the triathletes (Fig. 1).

At the end of the triathlon the subjects drew lots to decide the second test. This consisted of either a run which was identical in du ration to that of the triathlon, i.e. $2 \mathrm{~h} 15 \mathrm{~min}$ (Marathon Run, MR), or a 45 min run (Isolated Run, IR) which corresponded to the run time of the triathlon.

For the MR the subjects first ran for $1 \mathrm{~h} 20$ min on a flat track. Their instructions were to run at $60 \%$ of their maximum heart rate for the first $20 \mathrm{~min}$, then at $80 \%$ for the next hour. The blood sampling and the installation of the telemetric system required $8 \mathrm{~min}$ and was done after $1 \mathrm{~h} 20 \mathrm{~min}$. The subject then ran for $10 \mathrm{~min}$ at $80-85 \%$ of his maximum heart rate. During the last 45 min the running speed was adjusted lap by lap to be the same as that achieved in the triathlon. The IR was carried out under the same running conditions as the first trial. The time 
for each lap was imposed by a sound signal and was identical to that achieved in the triathlon. All the subjects had 30 min warm up time where they alternated between jogging and stretching.

All the trials took place between April and June in Paris, France. Outside temperature ranged from 19 to $26^{\circ} \mathrm{C}$, while indoor temperature ranged from 22 to $27^{\circ} \mathrm{C}$ with no wind and no rain. Subjects were encouraged to ingest $250 \mathrm{ml}$ of water during the cycling and $500 \mathrm{ml}$ during the triathlon run. During the first part of the MR, subjects absorbed $250 \mathrm{ml}$ of water and $500 \mathrm{ml}$ in the second part. It was left up to the subjects to decide when they wanted to drink. Only 250 $\mathrm{ml}$ of water were taken during the IR. In swimming the mean distance covered was $1433 \pm$

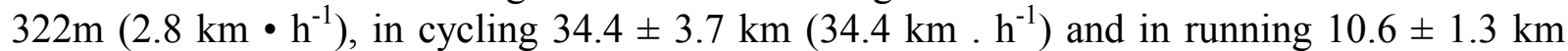
$\left(14.1 \mathrm{~km} \cdot \mathrm{h}^{-1}\right)$. The different changeover times are not included in the duration times for the triathlon and the marathon.

\section{Oxygen uptake measurements}

In order to measure the energy cost of running, the oxygen uptake was measured using the K2 Telemetric System (Cosmed, Milan, Italy). The system was described previously by Peel and Utsey (1993). Signals are transmitted by telemetry from a lightweight device that is worn by the subject to a receiver unit. Subjects wear a face mask with a turbine flowmeter attached. However, the unit does not contain a carbon dioxide gas analyser. Consequently, to calculate $0_{2}$, it is hypothesized that the volume of inspired air is equal to the volume of expired air, i.e. the respiratory exchange ratio (RER) is equal to 1 . The validity and the accuracy of the K2 system were previously determined $(24,30)$. In our experiment, data were gathered during the first 5 min of running $(0-5)$, during the 15 th to 25 th $\min (15-25)$ and during the 35 th to 45 th min (35-45) in order to give the subjects a minimum of respiratory discomfort and to let them drink during the trial (Fig. 1). The calculation of the energy cost of running $(\mathrm{Cr})$ was done using the formula given by Di Prampero (1986):

$$
\mathrm{Cr}\left(\mathrm{ml} \text { of } \mathrm{O}_{2} \cdot \mathrm{min}^{-1} \cdot \mathrm{km}^{-1}\right)=\frac{\mathrm{VO}_{2}\left(\mathrm{ml} \mathrm{of}_{2} \cdot \mathrm{min}^{-1} \cdot \mathrm{kg}^{-1}\right)}{\operatorname{Speed~}\left(\mathrm{km} \cdot \mathrm{h}^{-1}\right)}
$$

Heart rate was monitored using a Baumann unit (BHL 6000, Baumann and Haldi, Fleurier, Switzerland).

\section{Blood sample processing}

Blood samples were collected from an antecubital vein. Plasma was separated from the blood by a centrifuge at $3,000 \mathrm{rpm}\left(10 \mathrm{~min}\right.$ at $\left.4^{\circ} \mathrm{C}\right)$, divided into $0.5 \mathrm{ml}$ test-tubes then frozen quickly with liquid nitrogen. Samples were stored at $-20^{\circ} \mathrm{C}$.

Assays

Venous blood samples were used to determine the glucose concentration using a standard kit (Boehringer Mannheim, Meylan, France), and blood lactate concentration using an enzyme method (2). Plasma FFA concentrations were determined using a commercially available kit (Nefs C-test Wako, Biomérieux, Lyon, France). The plasma glycerol concentration was determined by an enzymatic method (13). The hematocrit, which is associated to the decrease in the plasma volume, was measured in duplicate using a micro-hematocrit centrifuge. The changes in plasma volume (MIN) were estimated using the Harrison's formula (1985): 


\section{$\% \Delta \mathrm{PV}=100 \frac{\mathrm{Ht}_{2}-\mathrm{Ht}_{2}}{\mathrm{Ht}_{2}} \times \frac{100}{100 \times \mathrm{Ht}_{1}}$}

where $\mathrm{Ht}_{1}$ is the pre-exercise hematocrit value and $\mathrm{Ht}_{2}$ is the post-exercise value.

Plasma renin activity (PRA) was determined radioimmunologically with a commercially available kit (Irakit CEA, France). Blood catecholamines (epinephrine, norepinephrine) were determined by a radioenzyme method derived from that of Da Prada and Zurcher (1976), and adapted for small volumes (15).

\section{Stride length measurements}

The heel strike was recorded by an Alcyon contact device (Alcyon Electronique, Beynes, France) placed in the runner's right shoe and the stride rate per lap was then calculated. This was connected to an energy supply and to a portable analogic recorder TEAC HR-30 (TEAC Corporation, Musashino Center, Tokyo, Japan). The stride length was then calculated by dividing the length lap by the stride number.

\section{Statistics}

The global analysis of the evolution of different parameters in relation to the time of the trial and the situation (TR, MR and IR) was carried out using a two-way variance analysis plan ( $2 \mathrm{x}$ $3)$. The comparison of the response variables between two experimental conditions was done using a Student's t-test for paired samples. All results are expressed as means \pm SEM. The level or confidence was set at $\mathrm{p}<0.05$.

\section{Results}

Table 1 shows the mean speeds at the start (T1: 0 - $5 \mathrm{~min}$ ), in the middle (T2: 15-25 min) and at the end of each trial (T3: 35-45 min). Although no statistically significant difference was noted, the running speed recorded during the triathlon run tended to progressively decrease from the beginning to the end of the trial. According to the experimental protocol, the running speeds imposed during MR and IR did not differ from those measured during TR.

\section{Ventilation parameters}

The variance analysis demonstrates a global effect of the exercise $(\mathrm{p}<0.01)$ on $\mathrm{VO}_{2}($ Table 1$)$. In comparison with the TR and the IR, the MR leads to a higher $\mathrm{VO}_{2}$ throughout the trial. For $\mathrm{T} 1, \mathrm{~T} 2$ and $\mathrm{T} 3$ the $\mathrm{VO}_{2}$ in the triathlon is higher than that calculated during IR $(\mathrm{p}<\mathrm{c} 0.05)$. Fig. 2 shows the changes in $\mathrm{Cr}$ in relation to the 45 min running done under MR, TR and IR conditions. The initial values are $205 \pm 2.1 \mathrm{ml} . \mathrm{kg}^{-1} \cdot \mathrm{km}^{-1}, 220.5 \pm 0.8 \mathrm{ml} . \mathrm{kg}^{-1} . \mathrm{km}^{-1}, 235.6 \pm$ $2.6 \mathrm{ml} \cdot \mathrm{kg}^{-1} \cdot \mathrm{km}^{-1}$, for the IR, TR and MR, respectively. The variance analysis shows that both the time and the type of activity have a significant effect on the $\mathrm{Cr}$ values $(\mathrm{p}<0.01)$. At the beginning of the running trial $\mathrm{Cr}$ was higher during MR than during both TR and IR $(+7 \%, \mathrm{p}$ $<0.01$, and $+15 \%, \mathrm{p}<0.01$, respectively). At the end of the trial $\mathrm{Cr}$ was higher during $\mathrm{MR}$ than during both TR and IR $(+10 \%, p<0.01$, and $+19 \%, p<0.01$, respectively). Moreover, the variance analysis for each run showed a global effect of the time on $\mathrm{VO}_{2}$ during the marathon run and the triathlon run; there is no statistical difference during the isolated run.

Table 1 shows that the pulmonary ventilation $(\mathrm{VE})$ is affected by the type of exercise $(\mathrm{p}<0.01)$. 
The mean total of pulmonary ventilation cumulated during MR $\left(108.3 \pm 2.51 . \mathrm{min}^{-1}\right)$ is higher $(\mathrm{p}<0.01)$ than the mean value recorded during both TR $\left(101.1 \pm 2.21 . \mathrm{min}^{-1}\right)$ and IR $(89.5 \pm$ 1.31. $\left.\mathrm{min}^{-1}\right)$. At the beginning of the trial there was no significant difference between the mean ventilation for the TR and the MR; changes become significant at the end of the trial $(\mathrm{p}<$ $0.01)$.

For T1, the mean heart rate in MR was significantly higher $(\mathrm{p}<0.05)$ than that in the triathlon; values recorded during both MR and TR were higher than those recorded during IR $(p<0.01$ and $\mathrm{p}<0.05)$, respectively. The mean heart rate during MR was significantly greater than that recorded during TR $(+7 \%, \mathrm{p}<0.01)$ and $\mathrm{IR}(+14 \%, \mathrm{p}<0.01)$ at T3.

\section{Hydration assessment (Table 2)}

The triathlon and the marathon events were associated with a greater $(\mathrm{p}<0.01)$ weight loss $(2.4 \pm 03 \mathrm{~kg})$ than the isolated run $(1 \pm 0.2 \mathrm{~kg})$. Temperature rises of $+1.8 \pm 0.1 \mathrm{t}$ for the triathlon and of $+2.1 \pm 0.1 \mathrm{t}$ for the marathon were recorded. At the end of the exercices, the hematocrit values for both the TR and the MR were significantly higher than that measured at the end of the IR $(p<0.01)$. In addition, there was a significant difference between hematocrit values observed during TR and MR $(+8.6 \%, \mathrm{p}<0.01)$. The recovery values were comparable with those obtained before each trial. The hematocrit values were used to calculate the changes in plasma volume. The most important decrease in plasma volume, as estimated by hematocrit changes for the MR appeared at the end of the run (-16.1\%). For the triathlon, plasma volume decreased regularly throughout the trial: $-10.4 \%$ after the cycling and $-14.6 \%$ after the run. The IR produced a non-significant decrease in plasma volume $(2 \%)$.

The type of exercise $(\mathrm{p}<0.05)$ and the time $(\mathrm{p}<0.01)$ had a significant global effect on PRA. PRA values recorded at the end of both the TR and MR were significantly higher than those obtained during the IR $(\mathrm{p}<0.01)$. Moreover, the recovery values were similar to those recorded before each trial.

\section{Metabolic and hormonal parameters}

The swimming and cycling trials (Table 3$)$ produced a significant increase $(p<0.01)$ in blood lactate in comparison with rest values. At the end of the trial the blood lactate measured for the triathlon $(3.5 \pm 0.21 \mathrm{mM})$ was not significantly different from that measured after the MR (4.1 $\pm 0.41 \mathrm{mM})$. These two values are significantly higher than those measured at the end of the $\operatorname{IR}(\mathrm{p}<0.01)$.

The blood glucose measured at the end of the marathon was significantly higher than that observed at the end of the IR $(\mathrm{p}<0.05)$ (Table 3).

Plasma FFA increased progressively during TR and MR (Table 3). Plasma FFA values measured at the end of the MR were higher than those measured after the TR $(p<0.05)$. These values were also significantly higher than the value measured after the IR $(0.77 \pm 0.1 \mathrm{mM})$. Plasma glycerol concentrations were paralleled with FFA values (Table 3). Values measured after both MR and TR were significantly higher than those recorded during IR $(0.054 \pm 0.002$ $\mu \mathrm{M})$.

The type of exercise and the time have a global effect $(\mathrm{p}<0.01)$ on the plasma catecholamine concentrations (epinephrine, norepinephrine). At the end of TR, both plasma epinephrine and norepinephrine concentrations were significantly higher than values measured after the MR ( $p$ $<0.05)$, and the IR $(\mathrm{p}<0.01)$ (Table 4). 


\section{Stride length}

Both type of exercise $(p<0.01)$ and time of measurement $(p<0.05)$ have a global effect on stride length (Fig. 3). From the start of the MR, the mean stride length was significantly shorter than during the IR $(1.29 \pm 0.03 \mathrm{~m}$ vs. $1.45 \pm 0.07 \mathrm{~m}, \mathrm{p}<0.05)$. This difference becomes even more significant towards the end of the trial $(1.16 \pm 0.03 \mathrm{~m}$ vs $1.34 \pm 0.07 \mathrm{~m}, \mathrm{p}$ $<0.01)$. A significant decrease in mean stride length between T1 and T2 during MR $(-8.4 \%)$, and a global decrease of $11.2 \%$ between T1 and T3 was also noted. The mean stride length during TR was significantly longer than that estimated during MR, at both T2 $(+13.4 \%$, p < $0.05)$ and $\mathrm{T} 3(+15.5 \%, \mathrm{p}<0.01)$.

\section{Discussion}

The first interesting finding of this study was the confirmation of the decrease in running economy at the end of an overground triathlon event. In addition, the results show that a $2 \mathrm{~h} 15$ min running bout brings about a decrease in running economy. Consequently, both single- and three-event endurance exercices bring about a decrease in running economy. For MR and TR, the mean energy cost values increase between the beginning and the end of the running bout. The energy cost of running $(\mathrm{Cr})$ for MR is $35 \mathrm{ml}$ of $0_{2}, \mathrm{~min}^{-1}-\mathrm{km}^{-1}$ higher than that calculated during IR and $18 \mathrm{ml}$ of $0_{2}, \mathrm{~min}^{-1}, \mathrm{~km}^{-1}$ more than for TR. One of the major findings of this study was that the alteration in running economy that occurred during the MR was more significant than during TR.

In the present study, the results show a higher energy cost of running at the end of a classic triathlon than that for a control run. The mean value for energy cost measured during the control run remained constant throughout the trial. This value seems relatively close to those obtained by different authors who have studied running under natural environments $(1,26)$. The increase in energy cost of running was associated with an increase of 111, min' in ventilation and this is in agreement with the results obtained in the laboratory (23). The significant increase of the expiratory flow partly explain the enhancement in $\mathrm{VO}_{2}$. Moreover, the mean stride length measured along the 45 min run following swimming and cycling did not differ from the values measured along the control run. These results suggest that the alteration in stride length was not a major factor that affects running economy at the end of a classic triathlon.

Although the athletes were constantly encouraged to drink fluids, an alteration in fluid balance occurred during the triathlon. A significant decrease in plasma volume as estimated by weight loss and increases in hematocrit and hemoglobin was recorded at the end of the triathlon. The $2.4 \mathrm{~kg}$ weight loss during the triathlon is comparable to values previously noted (23). The $14.6 \%$ decrease in plasma volume noted in our experiment at the end of the triathlon is very close to the $14.3 \%$ recorded by McNaughton (1989) alter a short distance triathlon. It has been shown that PRA increased during exercise, according to the work load (8). In addition, PRA is sensitive to dehydration and changes in position (18). Results of the present study demonstrated that PRA measured at the end of TR was higher than that recorded after IR. This increase could be related to the duration of the triathlon and the fluid imbalance. Because the triathlon event requires several changes in body position, the rise of PRA to assess the fluid balance may be questioned. Results of the present study suggest that fluid loss impaired the maintenance of optimal body temperature within optimal limits. This assumption is ascertained by a significant increase in body temperature at the end of the TR. It has been previously shown that an increase in core temperature led to an increase in $\mathrm{VO}_{2}$ and to a decrease in running economy (25). 
The results of our experiment confirm the decrease in the energy efficiency that occurred during a marathon in comparison with an isolated run for a similar running speed (5). The increase in $\mathrm{VO}_{2}$ recorded in the present study is higher than that reported by Bruckner et al. (1991) (15\% vs $5 \%$ ). The oxygen uptake and then $\mathrm{Cr}$ appear to be affected by fatigue occurring during the marathon. Accordingly, we could hypothesize that the triathletes who were not as well trained as the specialist runners, experience greater changes in their neuromuscular coordination at the end of a long during running exercise in contrast to a specialist rumen This decrement in running economy during MR could partially explain the greater difficulty the runner has in reproducing the running speed freely chosen during TR. Biomechanical factors could affect energy cost of running. The mean stride length in the marathon for $\mathrm{T} 1$ is $12.4 \%$ shorter $(\mathrm{p}<0.05)$ than that at the start of the isolated run. This difference might be linked to a $13.2 \%$ change in $\mathrm{VO}_{2}$ for the two trials: these results show that during the isolated run done at $75 \% \mathrm{VO}_{2} \max$ the athletes adapt themselves in stabilizing their $\mathrm{VO}_{2}$ to the imposed speed and stretched out their stride length in comparison with the MR. Moreover, we explain the reduction of the stride length during the isolated run by the fast that the subjects have to index their running speed to the one obtained during the triathlon run, speed which decreased non significantly from 14.8 to $13.7 \mathrm{~km} \mathrm{~h}^{-1}$ during the isolated run. Whether the $\mathrm{VO}_{2}$ changes were in relation with similar changes in stride length varies according to the studies. Högberg (1952) noted a $\mathrm{VO}_{2}$ increase of $11.9 \%$ for a $13.3 \%$ increase in stride length, but a $12 \%$ decrease in length is linked to only a $6 \%$ change in $\mathrm{V}_{2}$. Contrary to this, Cavanagh and Williams (1982) noted for their subjects, who were all athletes, exactly the same difference in $\mathrm{VO}_{2}$ for an increase or a decrease in stride length.

Although fluid ingestion was encouraged during the MR, a Jack of fluid balance was suggested by both weight loss and a higher level of hematocrit and hemoglobin at the end of the marathon run. The $1.9 \mathrm{~kg}$ weight loss during the marathon is close to the $1.6 \mathrm{~kg}$ noted by Boudou et al. (1987). In addition we have obtained a $2 \%$ decrease in plasma volume for the isolated run. These data suggest that the water loss was not compensated by the $750 \mathrm{ml}$ of water drunk during the marathon event.

One interesting finding of this experiment is that the energy cost of running during MR was significantly higher than that measured during TR. Moreover, we noted a smaller difference in $\mathrm{VO}_{2}$ between the triathlon run and the isolated run $(8.6 \%)$ than between the marathon run and the isolated run $(15.8 \%)$. For the triathlon and the marathon, the mean energy cost values increased along the run. The higher $\mathrm{Cr}$ measured during the marathon in comparison with the triathlon $\mathrm{Cr}$ was associated with the obvious difficulty the runner has in reproducing the speed acquired during the triathlon. Moreover, in comparison with TR, the decrease in running economy measured during MR was associated with a similar decrease in the stride length. These alterations could be linked to biomechanical factors related to decrease in glycogen muscle stores and to enhancement in eccentric muscle work. In a previous study, Williams and Cavanagh (1987) have shown that different biomechanical parameters such as stride length or the angles formed by parts of the lower limb during the race are related to the $\mathrm{Cr}$ and the performance of $10 \mathrm{~km}$ race runners. The relation between kinematics parameters and energy expenditure demonstrates the importance of the subject's choice of a stride frequency (or stride length). The energy cost of running has been described as a $U$ curve, in which the optimum point for energy expenditure (measured by $\mathrm{VO}_{2}$ ) corresponds to the stride frequency freely chosen by the subject. Contradictory results were noted for the effect of fatigue on changes in energy cost. Daniels (1985) suggests that fatigue is likely to have a direct effect on energy cost. However, what kind or amount of change this effect has does not seem to have been determined. Some studies show a decrease in energy cost when fatigue appears (7), others note a leveling off (35) and still others show an increase $(23,5)$. These studies indicate the need for further studies to verify the role of stride length, angles formed by body segments and the 
necessity to analyse the electromyographic activity of the main muscle groups involved in running.

Several studies have shown that during a prolonged effort, oxygen uptake increased when mechanical work remained constant (22,37).1t is possible to account for part of this phenomena by the modifications of metabolic ways taking place after prolonged exercise. Long duration exercise leads to a decrease in glycogen stores together with a progressive increase in the use of the fatty acids to replace carbohydrates as energy source (16). The increase in circulating FFA and glycerol at the end of the triathlon and marathon bear witness to this phenomena. The marathon led to a higher increase in lipolysis (FFA, glycerol) than the triathlon. According to Brueckner et al. (1991), this preferential use of lipids could partly explain the increase in energy cost for long duration trials, lipolysis using more oxygen than glycolysis for the same amount of energy. Moreover, glycemia rose very slightly after the triathlon and the single run, and rose significantly at the end of the marathon. The results are in agreement with those noted in the literature (4). However, no significant difference was recorded between the marathon and the triathlon, underlining the fact that without the addition of exogenous glucose solutions, the endogenous hepatic reserves are sufficient to maintain a quasi-stability in glycemia between the two long duration efforts. In addition, we hypothesize that motor units recruitment should be different during running versus bicycling. This may induce that at the beginning of the experimental run (i.e. after $1 \mathrm{~h} 30 \mathrm{~min}$ ) the muscular groups should have different glycogenic reserves to produce the same running speed.

On the other hand, in our experimental conditions, the lower values in heart rate during the triathlon as compared to the marathon were linked to a non significant drop in plasma volume. The thermophysiological adjustments clearly seem to be more pronounced for long duration efforts ( $>2$ hours), but this state does not fully explain the difference in energy cost of running between the triathlon and the marathon.

The plasma rates for norepinephrine noted at the end of the triathlon were significantly higher than those at the end of the marathon. The epinephrine values followed the same pattern as those for norepinephrine, however the concentrations of epinephrine measured at rest before the triathlon were twice as high as those for the other two trials. Up to now, we have very little data concerning catecholamine responses during a triathlon. It has been established that the concentration of plasma catecholamines increases with the intensity of muscular exercise $(17,33)$, exercise duration (17) and hyperthermia (32). Under the conditions of this study, the completion of the marathon was associated with a greater shift in heart rate, and a lower norepinephrine value than after the triathlon.

In conclusion, the results of this present study confirm the decrease in running economy during an overground triathlon. This decrement could be mainly linked to physiological factors such as the enhancement of core temperature and a lack of fluid balance. One interesting finding of this study is that a $2 \mathrm{~h} 15$ min run leads to a greater physiological alteration than a triathlon lasting the same time. This change in running efficiency could be related to biomechanical factors such as the alteration in stride length. Moreover, the marathon event was associated with both physiological and biomechanical impairments in comparison with an isolated run done at the same speed. 


\section{Acknowledgements}

The authors thank Dr. Joussellin and Dr. Vallier for their assistance with collection of the blood samples.

\section{References}

1.Bassett D. R., Giese M. D., Nagel F. J., Ward A., Raab D. M., Balke B.: Aerobic requirements of overground versus treadmill running. Med Sci Sports Exerc 17: 477-481, 1985.

2 Bergmeyer H. U.: Methods of Enzymatic Analysis. Academic Press, New York, 1974.

3 Boone T., Kreider R. B.: Bicycle exercise before running: effect on performance. Ann Sports Med 3: 25-29, 1986.

4 Boudou P., Fiet J., Laureaux C., Patricot M. C., Guezennec C. Y., Foglietti M. J., Villette J. M., Friemel F., Haag J. C.: Validons de quelques constituants plasmatiques et urinaires chez les marathoniens. Ani Biol Clin 45: 37-45, 1987.

5 Brueckner J. C., Atchou G., Capelli C., Duvallet A., Jousselin E., Rieu M.: The energy cost of running increases with the distance covered. Eur J Appl Physiol 62: 385-389, 1991.

6 Cavanagh P. R., Williams K. R.: The effect of stride length variations on oxygen uptake during distance running. Med Sci Sports Exerc 14: 30-35, 1982.

7.Cavanagh P. R., Kram R.: Stride length in distance running: velocity, body dimensions, and added mass effects. Med Sci Sports Exerc 21: 467-479, 1989.

8 Convertino V. A., Kiel C., Greenleaf J. E.: Plasma volume and renin and vasopressin responses to graded exercise after training. J Appl Physiol 54: 508 - 514, 1983.

9 Da Prada M., Zurcher G.: Simultaneous radioenzymatic determination of plasma and tissue adrenaline, noradrenaline and dopamine within the femtomole range. Life Sci 19: 1161 -1174, 1976.

10 Daniels J.: A physiolgist's view of running economy. Med Sci Sports Exerc 17: 332-338, 1985.

11.Davies C.: Effects of wind assistance and resistance on the forward motion of a runner. $J$ Appl Physiol 48: 702-709, 1980.

12 Di Prampero P. E.: The energy cost of human locomotion on land and in water. Int J Sports Med 7: 55 - 72, 1986.

13 Eggstein M., Kuhlman E.: Triglyceride and glycerol determination after alkaline hydrolysis. In: H. U. Bergmeyer "Methods of enzymatic analysis", Academic Press, New York, 1974, pp. $1825-1831$.

14 Elliot B. C., Roberts A. D.: A biomechanical evaluation of the role of fatigue in middle distance running. Can J Appl Sport Sci 5: 203-207, 1980. 
15.Fekete M. I. K., Kanyicska B., Herman J. P.: Simultaneous radioenzymatic assay of catecholamines and dihydroxyphenylacetic acid (DOPAC); comparison of the effects of drugs on the tubeoinfindibular and stratial dopamine metabolism and on plasma prolactin level. Life Sci 13: 1549-1556, 1978.

16 Felig P., Wahren J.: Fuel homeostasis in exercise. New EngI J Med 293: 1078-1084, 1975.

17 Galbo H., Holst J. J., Christensen N. J.: Glucagon and plasma catecholamines responses to graded and prolonged exercise in man. J Appl Physiol 38: 70- 76, 1975.

18 Guezennec C. Y., Defer G., Cazorla G., Sabathier C., Lhoste F.: Plasma renin activity, aldosterone and catecholamine levels when swimming and running. Eur J Appl Physiol 54: 632-637, 1986.

19 Harrison M. H.: Effects of thermal stress and exercise on blood volume in humans. Physiol Rev 15: 164-167, 1985.

20 Helgerud J.: Maximal oxygen uptake, anaerobic threshold and running economy in women and men with similar performances level in marathons. Eur J Appl Physiol 68: 155-161, 1994.

21 Högberg P.: Length of stride, stride frequency, "flight" period and maximum distance between the feet during running with different speeds. Arbeitsphysiologie 14: 431 -436, 1952.

22 Kreider R. B., Boone T., Thompson W. R., Burke S., Cortes C. W.: Cardiovascular and thermal responses of triathlon performance. Med Sci Sports Exerc 20: 385-390, 1988a.

23 Kreider R. B., Cundiff D. E., Hammet J. B., Cortes C. W., William K. W.: Effects of cycling on running performance in triathletes. Ann. Sports Med 4: 220-225, 1988b.

24 Lucia A., Fleck S. J., Gotshall R. W., Kearney J. T.: Validity and reliability of the Cosmed K2 instrument. Int J Sports Med 14: 380-386, 1993.

25 McDougall J., Reddan W., Layton C., Dempsey J.: Effects of metabolic hyperthermia on performant during heavy prolonged exercise. J Appl Physiol 36: 538-544 1974.

26 McMiken D. F., Daniels J. T.: Aerobi requirements and maximum aerobic power in treadmill and track running. Med Sci Sports 8: 14-17, 1976.

27 McNaughton L. M.: Plasma volume responses associated with a sprint triathlon in novice triathletes. Int J Sports Med 3: 161 - 164, 1989.

28 Morgan D. W., Martin P. E., Krahenbuhl G.: Factors affecting running economy. Sports Med 7: 310-330, 1989.

29 O'Toole M. L, Douglas P. S., Hiller W. D. B.: Applied physiology of a triathlon. Sports Med 8: 201-225, 1989.

30 Peel C., Utsey C.: Oxygen consumption using the K2 telemetry system and a metabolic cart. Med Sci Sports Exerc 25: 396-400, 1993.

31 Pugh L G. C. E.: Oxygen uptake in track and treadmill running with observations on the effect of air resistance. J Physiol 207: 823 -835, 1970. 
32 Shum A., Johnson G. E., Flattery K. V.: Influence of ambient temperature on excretion of catecholamines and metabolites. Am J Physiol 216: 1164-1169, 1969.

33 Sothmann M. S., Gustafson A. B., Chandler M.: Plasma free and sulfconjugated catecholamine responses to varying exercise intensity. J Appl Physiol 63: 654-658, 1987.

34 Town G. P.: Science of triathlon training and competition. Champaign, IL: Human Kinetics, 1985, pp. 4-56,

36 Wiliams K. R., Cavanagh P. R., Ziff J.: Biomechanical studies of elite female distances runners. Int J Sports Med 8: 107 -110,1987.

36 Williams K. R., Cavanagh P. R.: Relationship between distance running mechanics, running economy, and performance. J Appl Physiol 63: 1236 -1245, 1987.

$37 \mathrm{Xu}$ F., Montgomery D. L.: Effect of prolonged exercise at 65 and $80 \%$ of $\mathrm{VO}_{2} \mathrm{max}$ on running economy. Int J Sports Med 16: 309-315, 1995.

Figure 1 Graphic representation of the different unfolding events occurring during every experimentation.

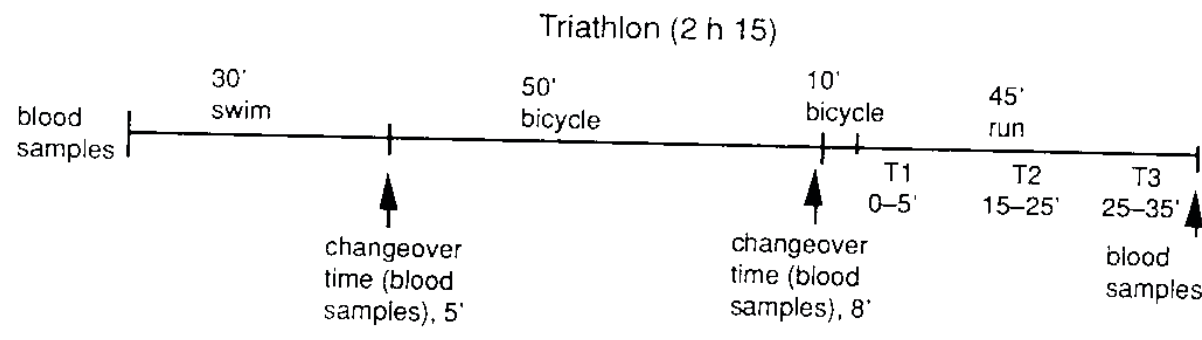

Marathon Run (2 h 15)

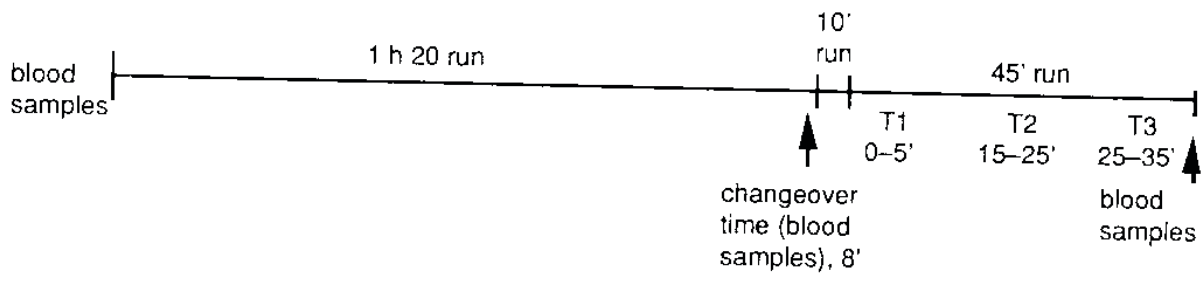

Isolated Run (45')

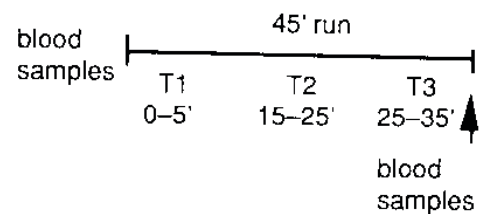


Figure 2Changes in Energy Cost during the Isolated Run (IR), the Marathon Run (MR) and the Triathlon Run (TR). Values are means $( \pm$ SE). From start to finish, Energy Cost values for MR and TR were significantly greater than for IR $(\mathrm{p}<\mathrm{c} 0.01)$. Moreover, each Energy Cost Value for MR was significantly greater than for TR $(p<0.01)$ during running.

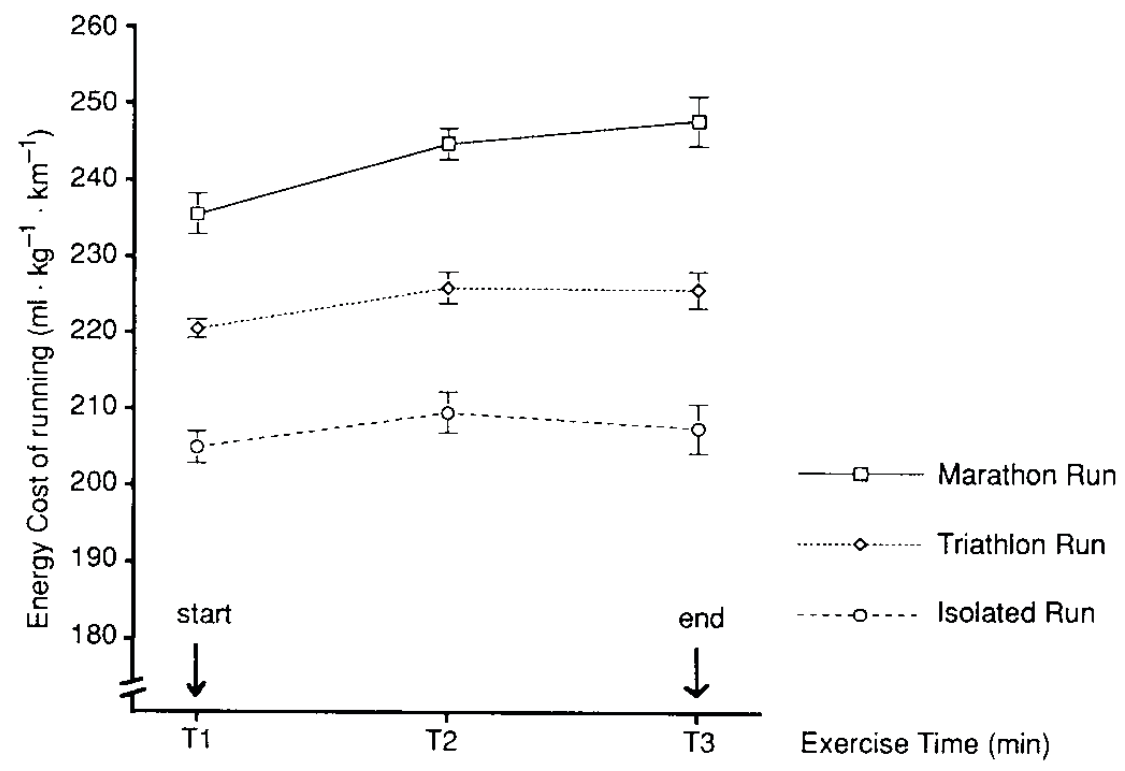

Figure 3 Changes in Stride Length values during the lsolated Run (IR), the Marathon Run $(\mathrm{MR})$ and the Triathlon Run (TR). Values are means $( \pm \mathrm{SE})$. Significantly different from correspondeing Marathon group, $a(p<0.05), b(p<0.01)$; significantly different from the beginning of the exercise, $\mathrm{c}(\mathrm{p}<0.05)$.

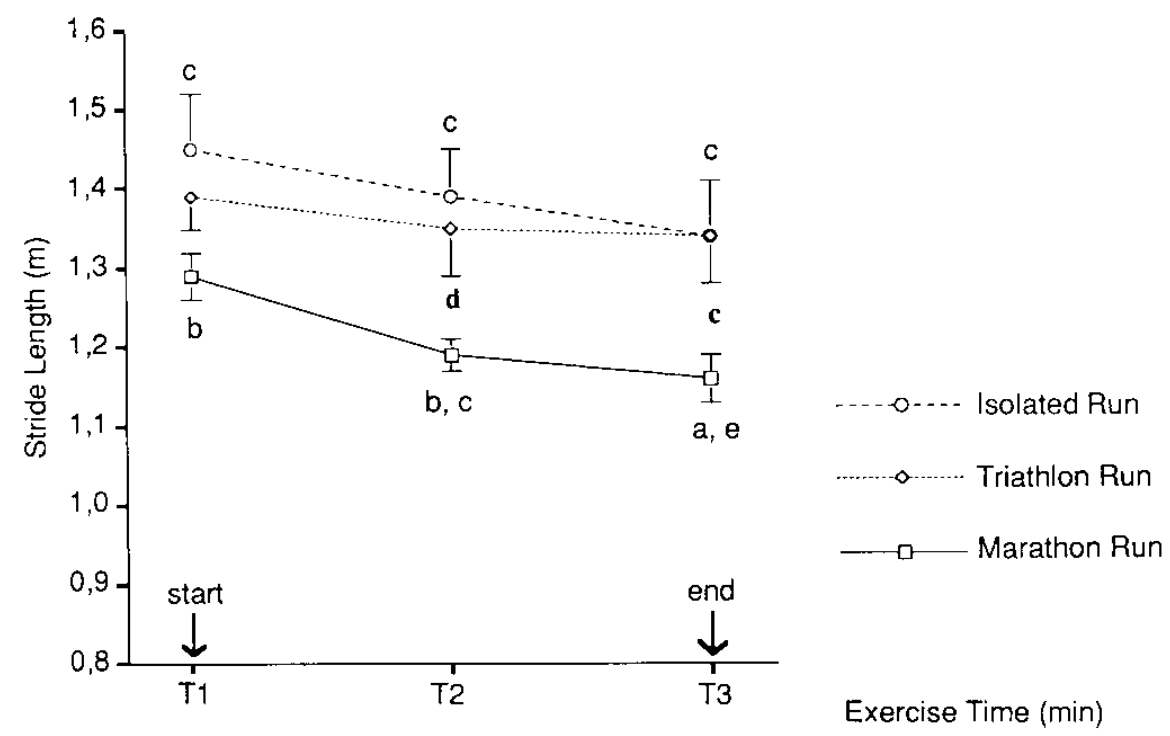


Table 1 Effects of the Triathlon Run (TR), the Marathon Run (MR) and the Isolated Run (IR) on the mean speed, the oxygen consumption, the expiratory flow and the heart rate obtained during 45 minutes of running. Values are means $( \pm \mathrm{SE})$.

\begin{tabular}{|c|c|c|c|c|c|c|c|c|c|c|c|}
\hline & \multicolumn{3}{|c|}{ Triathlon Run (min) } & \multicolumn{3}{|c|}{ Marathon Run (min) } & \multicolumn{3}{|c|}{ Isolated Run (min) } & \multicolumn{2}{|c|}{ ANOVA } \\
\hline Parameters & T1 & T2 & T3 & T1 & T2 & T3 & T1 & T2 & T3 & Situation & Time \\
\hline Speed $\left(\mathrm{km} \cdot \mathrm{h}^{-1}\right)$ & $\begin{array}{l}14.5 \\
\pm 0.6\end{array}$ & $\begin{array}{l}14.0 \\
\pm 0.6\end{array}$ & $\begin{array}{l}13.6 \\
\pm 0.7\end{array}$ & $\begin{array}{l}14.6 \\
\pm 0.6\end{array}$ & $\begin{array}{l}13.8 \\
\pm 0.5\end{array}$ & $\begin{array}{l}13.5 \\
\pm 0.7\end{array}$ & $\begin{array}{l}14.8 \\
\pm 0.7\end{array}$ & $\begin{array}{l}14.1 \\
\pm 0.6\end{array}$ & $\begin{array}{l}13.7 \\
\pm 0.7\end{array}$ & NS & NS \\
\hline $\begin{array}{l}\text { Oxygen uptake, } \mathrm{VO}_{2} \\
\left(\mathrm{ml} \cdot \mathrm{min}^{-1} \cdot \mathrm{kg}^{-1}\right)\end{array}$ & $\begin{array}{l}53.5 \bullet \\
\pm 2.1 \\
\end{array}$ & $\begin{array}{l}52.7 \mathrm{a}^{4} \\
2.2 \\
\end{array}$ & $\begin{array}{l}51.1^{\mathrm{ad}}, \\
2.6^{\mathrm{d}}\end{array}$ & $\begin{array}{l}57.2 \mathrm{~b} \\
2.1 \\
\end{array}$ & $\begin{array}{l}6.2 \mathrm{~b} \\
2.1 \\
\end{array}$ & $\begin{array}{l}55.5 \mathrm{~b} \\
2.4 \\
\end{array}$ & $\begin{array}{l}50.5 \\
2.4 \\
\end{array}$ & $\begin{array}{l}49.2 \mathrm{~d} \\
2.0 \\
\end{array}$ & $\begin{array}{l}47.9 \mathrm{~d} \\
1.8 \\
\end{array}$ & $\mathrm{p}<0.01$ & NS \\
\hline $\begin{array}{l}\text { Expiratory flow, VE } \\
\left(1 \cdot \min ^{-1}\right)\end{array}$ & $\begin{array}{l}104.4 \mathrm{~b} \\
\pm 3.2\end{array}$ & $\begin{array}{l}99.4 \mathrm{~b}, \mathrm{~d} \\
1.9\end{array}$ & $\begin{array}{l}99.76^{\bullet} \\
1.7 \\
\end{array}$ & $\begin{array}{l}109.1 \\
2.9\end{array}$ & $\begin{array}{l}107.6 \mathrm{~b} \\
2.3 \\
\end{array}$ & $\begin{array}{l}108.3 b \\
2.3\end{array}$ & $\begin{array}{l}90.8 \\
1.7 \\
\end{array}$ & $\begin{array}{l}89.3 \mathrm{~d} \\
0.8 \\
\end{array}$ & $\begin{array}{l}88.4 \mathrm{~d} \\
1.5 \\
\end{array}$ & $\mathrm{p}<0.01$ & NS \\
\hline $\begin{array}{l}\text { Heart rate, HR (beats } \\
\text { - } \min ^{-1} \text { ) }\end{array}$ & $\begin{array}{l}164^{8 \mathrm{a}, \mathrm{c}} \\
\pm 6.3\end{array}$ & $\begin{array}{l}172.6^{\mathrm{b}, \mathrm{d}} \bullet \\
4.8\end{array}$ & $\begin{array}{l}172.6^{\mathrm{bd}} \\
5.1\end{array}$ & $\begin{array}{l}171.0 \mathrm{~b} \\
6.0 \\
\end{array}$ & $\begin{array}{l}181.0^{\mathrm{b}} \\
5.0\end{array}$ & $\begin{array}{l}184.3^{\mathrm{b}} \\
5.1\end{array}$ & $\begin{array}{l}153.4^{\mathrm{d}} \\
6.9 \\
\end{array}$ & $\begin{array}{l}158.6^{\mathrm{d}} \\
4.6 \\
\end{array}$ & $\begin{array}{l}160.8^{\mathrm{d}} \\
6.0 \\
\end{array}$ & $\mathrm{p}<0.01$ & NS \\
\hline
\end{tabular}

Significantly different from IR group, ${ }^{a} \mathrm{p}<0.05,{ }^{b} \mathrm{p} 0.01$ Significantly different from MR group, ${ }^{\mathrm{c}} \mathrm{p}<0.05,{ }^{\mathrm{d}} \mathrm{p}<0.01$ 
Table 2 Changes in hematocrit, hemoglobin, plasma renin activity (PRA), body weight and rectal temperature and for a triathlon, a marathon or a 45 minute isolated run. Values are means $( \pm \mathrm{SE})$.

\begin{tabular}{|c|c|c|c|c|c|c|c|c|c|c|c|c|c|}
\hline \multirow{3}{*}{$\begin{array}{l}\text { Parameters } \\
\text { Hematocrit } \mathrm{Ht} \\
(\%)\end{array}$} & \multicolumn{4}{|c|}{ Triathlon } & \multicolumn{4}{|c|}{ Marathon } & \multicolumn{3}{|c|}{ Isolated Run } & \multirow{2}{*}{\multicolumn{2}{|c|}{$\begin{array}{r}\text { ANOVA } \\
\text { Situation-Time }\end{array}$}} \\
\hline & before & intermediate & end & recovery & before & intermediate & end & recovery & before & end & recovery & & \\
\hline & $\begin{array}{l}42.9 \\
\pm 1.8 \\
\end{array}$ & $\begin{array}{l}46.3^{\mathrm{h}} \\
\pm 1.3\end{array}$ & $\begin{array}{l}48.3^{\text {bdfh }} \\
\pm 1.3\end{array}$ & $\begin{array}{l}44.8 \\
\pm 1.3\end{array}$ & $\begin{array}{l}41.1 \\
\pm 1.5\end{array}$ & $\begin{array}{l}45.9^{\mathrm{h}} \\
\pm 1.5\end{array}$ & $\begin{array}{l}44.5^{\text {bfh }} \\
\pm 1.3\end{array}$ & $\begin{array}{l}41.5 \\
\pm 1.2\end{array}$ & $\begin{array}{l}42.9 \\
\pm 1.2\end{array}$ & $\begin{array}{l}43.4 \\
+1.1\end{array}$ & $\begin{array}{l}42.9 \\
\pm 1.1\end{array}$ & NS & $\mathrm{p}<0.01$ \\
\hline $\begin{array}{l}\text { Hemoglobin, } \\
\mathrm{Hb}(\%)\end{array}$ & $\begin{array}{l}14.4 \\
\pm 0.5\end{array}$ & $\begin{array}{l}15.3^{\mathrm{h}} \\
\pm 0.4\end{array}$ & $\begin{array}{l}15.8^{\text {ath }} \\
\pm 0.4\end{array}$ & $\begin{array}{l}14.8 \\
\pm 0.4\end{array}$ & $\begin{array}{l}14.0 \\
\pm 0.4\end{array}$ & $\begin{array}{l}15.6^{\mathrm{h}} \\
\pm 0.4\end{array}$ & $\begin{array}{l}15.1^{\text {ath }} \\
\pm 0.4\end{array}$ & $\begin{array}{l}14.2 \\
+0.4 \\
\end{array}$ & $\begin{array}{l}14.3 \\
\pm 0.3\end{array}$ & $\begin{array}{l}14.7 \\
\pm 0.2\end{array}$ & $\begin{array}{l}14.5 \\
\pm 0.3\end{array}$ & NS & $\mathrm{p}<0.01$ \\
\hline $\begin{array}{l}\text { Plasma volume } \\
\text { changes, } \Delta \mathrm{PV} \\
(\%)\end{array}$ & & $\begin{array}{l}12.8 \\
\pm 1.1\end{array}$ & $\begin{array}{l}19.6 \\
\pm 1.4\end{array}$ & & & $\begin{array}{l}17.6 \\
\pm 1.3\end{array}$ & $\begin{array}{l}12.9 \\
\pm 1.1\end{array}$ & & & $\begin{array}{l}2.0 \\
\pm 0.4\end{array}$ & & NS & $\mathrm{p}<0.01$ \\
\hline $\begin{array}{l}\text { Plasma renin } \\
\text { activity, } \\
\text { PRA(ng }-\mathrm{ml}^{-1} \\
\left.\cdot \mathrm{h}^{-1}\right)\end{array}$ & $\begin{array}{l}2.4 \\
\pm 0.4\end{array}$ & $\begin{array}{l}6.3^{\mathrm{c}, \mathrm{h}} \\
\pm 1.4\end{array}$ & $\begin{array}{l}25.6^{\mathrm{adh}} \\
\pm 0.5\end{array}$ & $\begin{array}{l}3.1 \\
\pm 0.6\end{array}$ & $\begin{array}{l}2.1 \\
\pm 0.3\end{array}$ & $\begin{array}{l}15.3^{\mathrm{h}} \\
\pm 1.2\end{array}$ & $\begin{array}{l}25.1^{\text {ath }} \\
\pm 0.7\end{array}$ & $\begin{array}{l}2.7 \\
\pm 0.6\end{array}$ & $\begin{array}{l}2.4 \\
\pm 0.6\end{array}$ & $\begin{array}{l}12.1^{\mathrm{g}} \\
\pm 1.7\end{array}$ & $\begin{array}{l}2.8 \\
\pm 0.7\end{array}$ & $\mathrm{p}<0.05$ & $\mathrm{p}<0.01$ \\
\hline $\begin{array}{l}\text { Body } \\
\text { weight }(\mathrm{kg})\end{array}$ & $\begin{array}{l}71.9 \\
\pm 2,1 \\
\end{array}$ & & $\begin{array}{l}69.5^{\mathrm{b}, \mathrm{h}} \\
\pm 2.1\end{array}$ & & $\begin{array}{l}71.8 \\
\pm 2.0 \\
\end{array}$ & & $\begin{array}{l}69.7^{\mathrm{b}, \mathrm{h}} \\
\pm 1.9\end{array}$ & & $\begin{array}{l}71.0 \\
\pm 2.4 \\
\end{array}$ & $\begin{array}{l}70.0 \\
\pm 2.4 \\
\end{array}$ & & NS & $\mathrm{p}<0.05$ \\
\hline $\begin{array}{l}\text { Rectal } \\
\text { Temperature } \\
\text { ( C) }\end{array}$ & $\begin{array}{l}73.3 \\
\pm 0.15\end{array}$ & & $\begin{array}{l}39.1 \text { b } \\
\pm 0.15\end{array}$ & & $\begin{array}{l}37.1 \\
\pm 0.15\end{array}$ & & $\begin{array}{l}39.2^{\mathrm{b}, \mathrm{h}} \\
\pm 0,18\end{array}$ & & $\begin{array}{l}37.1 \\
\pm 0.12\end{array}$ & $\begin{array}{l}37.9 \\
\pm 0.15\end{array}$ & & NS & $\mathrm{p}<0.01$ \\
\hline
\end{tabular}

Significantly different from Isolated run group, ${ }^{\mathrm{a}} \mathrm{p}<0.05,{ }^{\mathrm{b}} \mathrm{p}<0,01$

Significantly different from Marathon group, ${ }^{c} \mathrm{p}<0.05,{ }^{\mathrm{d}} \mathrm{p}<0.01$

Significantly different from intermediate values, ${ }^{\mathrm{e}} \mathrm{p}<0.05,{ }^{\mathrm{f}} \mathrm{p}<0,01$

Significantly different from resting values, ${ }^{\mathrm{g}} \mathrm{p}<0,05,{ }^{\mathrm{h}} \mathrm{p}<0.01$ 
Table 3 Changes in plasma glycerol, plasma free fatty acids (FFA), plasma lactatemia and plasma glucose for a triathlon, a marathon or a 45 min isolated run. Values are means $( \pm \mathrm{SE})$.

\begin{tabular}{|c|c|c|c|c|c|c|c|c|c|c|c|c|c|}
\hline & \multicolumn{4}{|c|}{ Triathlon } & \multicolumn{4}{|c|}{ Marathon } & \multicolumn{3}{|c|}{ Isolated Run } & \multirow{2}{*}{\multicolumn{2}{|c|}{$\begin{array}{c}\text { ANOVA } \\
\text { Situation-Time }\end{array}$}} \\
\hline Parameters & before & intermediate & end & recovery & before & intermediate & end & recovery & before & end & recovery & & \\
\hline Glycerol $(\mu \mathrm{M})$ & $\begin{array}{l}0.039 \\
\pm 0.001\end{array}$ & $\begin{array}{l}0.061^{\mathrm{g}} \\
\pm 0.004\end{array}$ & $\begin{array}{l}0.082^{\text {aceh }} \\
\pm 0.006\end{array}$ & $\begin{array}{l}0.046 \\
\pm 0.003\end{array}$ & $\begin{array}{l}0.048 \\
\pm 0.003\end{array}$ & $\begin{array}{l}0.080^{\mathrm{h}} \\
\pm 0.005\end{array}$ & $\begin{array}{l}0.111^{\text {beh }} \\
\pm 0.005\end{array}$ & $\begin{array}{l}0.045 \\
\pm 0.001\end{array}$ & $\begin{array}{l}0.042 \\
\pm 0.004\end{array}$ & $\begin{array}{l}0.054^{\mathrm{g}} \\
\pm 0.005\end{array}$ & $\begin{array}{l}0.048 \\
\pm 0.001\end{array}$ & $\mathrm{p}<0.01$ & $\mathrm{p}<0.01$ \\
\hline $\begin{array}{l}\text { Free Fatty Acid, } \\
\text { FFA }(\mathrm{mM})\end{array}$ & $\begin{array}{l}0.16 \\
\pm 0.30\end{array}$ & $\begin{array}{l}0.60^{\mathrm{h}} \\
\pm 0.14\end{array}$ & $\begin{array}{l}1.10^{\text {aech }} \\
\pm 0.20\end{array}$ & $\begin{array}{l}0.23 \\
\pm 0.08\end{array}$ & $\begin{array}{l}0.12 \\
\pm 0.02\end{array}$ & $\begin{array}{l}0.78^{\mathrm{h}} \\
\pm 0.20\end{array}$ & $\begin{array}{l}1.70^{\text {beh }} \\
\pm 0.20\end{array}$ & $\begin{array}{l}0.18 \\
\pm 0.40\end{array}$ & $\begin{array}{l}0.15 \\
\pm 0.20\end{array}$ & $\begin{array}{l}0.77^{\mathrm{g}} \\
\pm 0.10\end{array}$ & $\begin{array}{l}0.18 \\
\pm 0.30\end{array}$ & NS & $\mathrm{p}<0.01$ \\
\hline $\begin{array}{l}\text { Lactatemia, }\left[\mathrm{La}^{-}\right. \\
](\mathrm{mM})\end{array}$ & $\begin{array}{l}0.9 \\
\pm 0.06\end{array}$ & $\begin{array}{l}5.2^{\mathrm{dh}} \\
\pm 0.41\end{array}$ & $\begin{array}{l}3.5^{\text {bfh }} \\
\pm 0.21\end{array}$ & $\begin{array}{l}1.9 \\
\pm 0.05\end{array}$ & $\begin{array}{l}0.9 \\
\pm 0.11 \\
\end{array}$ & $\begin{array}{l}2.4 \mathrm{~h} \\
\pm 0.17\end{array}$ & $\begin{array}{l}4.1^{\text {bfh }} \\
\pm 0.41\end{array}$ & $\begin{array}{l}1.9 \\
\pm 0.24\end{array}$ & $\begin{array}{l}0.9 \\
\pm 0.05\end{array}$ & $\begin{array}{l}2.29 \\
\pm 0.08 \\
\end{array}$ & $\begin{array}{l}1.2 \\
\pm 1.2\end{array}$ & $\begin{array}{l}\mathrm{p}< \\
0.01\end{array}$ & $\mathrm{p}<0.01$ \\
\hline Glucose (mM) & 4.81 & 4.94 & 5.18 & 4.92 & 4.75 & 5.32 & $5.58^{\mathrm{ag}}$ & 4.68 & 4.58 & 4.81 & 4.71 & NS & NS \\
\hline & \pm 0.88 & \pm 0.91 & \pm 0.94 & \pm 0.79 & \pm 0.87 & \pm 0.95 & \pm 0.68 & \pm 0.91 & \pm 0.87 & \pm 0.74 & \pm 0.84 & & \\
\hline
\end{tabular}

Significantly different from Isolated Run group, ${ }^{a} p<0.05,{ }^{b} p<0.01$

Significantly different from Marathon group, ${ }^{c} p<0.05,{ }^{d} p<0,01$

Significantly different from intermediate values, ${ }^{e} p<0,05,{ }^{f} p<0,01$

Significantly different from resting values, ${ }^{\mathrm{g}} \mathrm{p}<0,05,{ }^{\mathrm{h}} \mathrm{p}<0,01$ 
Table 4 Changes in plasma catecholamines (norepinephrine, epinephrine) for a triathlon, a marathon or a 45 min isolated run,

Values are means $( \pm \mathrm{SE})$.

\begin{tabular}{|l|l|l|l|l|l|l|l|l|l|l|l|}
\hline & \multicolumn{3}{|c|}{ Triathlon } & \multicolumn{3}{c|}{ Marathon } & \multicolumn{3}{c|}{ Isolated Run } & \multicolumn{2}{c|}{ ANOVA } \\
\hline Parameters & before & end & recovery & before & end & recovery & \multicolumn{2}{l|}{ before } & end & recovery & Situation-Time \\
\hline Norepinephrine $(\mathrm{pg} / \mathrm{ml})$ & $\begin{array}{l}598 \\
\pm 71\end{array}$ & $4021^{\text {bcf }}$ & 872 & 415 & $2590^{\text {af }}$ & 536 & 456 & 1158 & 550 & $\mathrm{p}<0.01$ & $\mathrm{p}<0.01$ \\
\hline Epinephrine $(\mathrm{pg} / \mathrm{ml})$ & $\begin{array}{l}64.0^{\text {ac }} \\
\pm 7.9\end{array}$ & $210.1^{\mathrm{bcf}}$ & 52.6 & 36.2 & $133.8^{\text {af }}$ & 34.2 & 36.2 & 52,6 & 34.6 & $\mathrm{p}<0.01$ & $\mathrm{p}<0.01$ \\
\hline
\end{tabular}

Significantly different from Isolated Run group, ${ }^{\mathrm{a}} \mathrm{p}<0.05,{ }^{\mathrm{b}} \mathrm{p}<0.01$

Significantly different from Marathon group, ${ }^{c} \mathrm{p}<0,05,{ }^{\mathrm{d}} \mathrm{p}<0,01$

Significantly different from resting values, ${ }^{e} p<0,05,{ }^{f} p<0,01$ 